\title{
Ionic Liquid Based Ultrasonic-Assisted Extraction of Oleanolic Acid from Grape Seeds
}

\author{
Xifeng Zhang1,2, Xue Li1', Qian He1, Bin Zhang1, Xue Zheng1,2* \\ ${ }^{1}$ The College of Agriculture and Biotechnology (CAB), Hexi University, Zhangye, China \\ ${ }^{2}$ Key Laboratory of Hexi Corridor Resources Utilization of Gansu, Zhangye, China \\ Email: *curiouslysxsd@163.com
}

How to cite this paper: Zhang, X.F., Li, X., He, Q., Zhang, B. and Zheng, X. (2017) Ionic Liquid Based Ultrasonic-Assisted Extraction of Oleanolic Acid from Grape Seeds. Open Access Library Journal, 4: e4148. https://doi.org/10.4236/oalib.1104148

Received: November 13, 2017

Accepted: December 17, 2017

Published: December 20, 2017

Copyright $(\odot) 2017$ by authors and Open Access Library Inc.

This work is licensed under the Creative Commons Attribution International License (CC BY 4.0).

http://creativecommons.org/licenses/by/4.0/

(c) (i) Open Access

\begin{abstract}
Ionic liquid based ultrasonic-assisted extraction (ILUAE) was successfully applied to extract Oleanolic acid (OA) from grape seeds. Different kinds of 1-alkyl-3-methylimidazolium ionic liquids with different kinds of cations and anions were studied and 1-butyl-3-methylimidazolium chloride $\left(\left[\mathrm{C}_{4} \mathrm{mim}\right] \mathrm{Cl}\right)$ solution was selected as extractants. The optimal conditions of ILUAE were determined by single factor experiments and Box-Behnken design as follows: $\left[\mathrm{C}_{4} \mathrm{mim}\right] \mathrm{Cl}$ concentration of $0.7 \mathrm{~mol} / \mathrm{L}$, extraction time of $4 \mathrm{~h}$, liquid-solid ratio of $15: 1 \mathrm{~mL} / \mathrm{g}$, ultrasonic power of $195 \mathrm{~W}$, the ultrasonication time of 13 min, and extraction temperature of $48^{\circ} \mathrm{C} \cdot \mathrm{min}$. The extraction yield of $\mathrm{OA}$ was $13.4 \mathrm{mg} / \mathrm{g}$, which is well in close agreement with the value predicted by the model. Compared with the regular ultrasonic-assisted extraction (UAE), the proposed approach exhibited 1.64 times higher efficiency, which indicated that ILUAE has a broad prospect for sample preparation of the bioactive compounds.
\end{abstract}

\section{Subject Areas}

Agricultural Science, Food Science \& Technology

\section{Keywords}

Ionic-Liquid Based Ultrasound-Assisted (ILUAE), Oleanolic Acid, Grape Seeds

\section{Introduction}

The total production of grapes worldwide is about 60 million-tons per year, particularly in France, Italy, the USA and China. Approximately $80 \%$ of this harvest is used in wine production, with the remaining $20 \%$ of the processed grape being 
waste [1] [2]. Grape seeds are by-products of the wine and grape juice industry. These seeds contain lipid, protein, carbohydrate, polyphenols and triterpenoids [3] [4] [5]. Triterpenoids are important due to their high medicinal value; and oleanolic acid (OA) which is triterpenoid is major active substance. Figure 1 shows the chemical structure of oleanolic acid. Many researchers have studied the beneficial effects of OA in grapes and wines on human health [6]. These benefits include antioxidant activity [7], anti-inflammatory [8], anticancer activity [9], and others [10].

Different techniques have been employed for the extraction of OA such as heat reflux, hydrotropic extraction, microwave assisted extraction, and supercritical fluid extraction [11] [12]. Heat reflux extraction and maceration extraction techniques have drawbacks of requiring longer extraction time and relatively large volumes of solvents. Supercritical fluid extraction method requires expensive high pressure equipment and may also require organic solvents as co-solvents for complete extraction of the bioactives. Therefore, in recent years there is an increasing demand for new eco-friendly extraction techniques with shorter extraction time, maximum extraction efficiency and with reduced requirement of organic solvents.

In this study, we report an ionic liquid based ultrasonic-assisted extraction (ILUAE) as an alternative method for the recovery of OA. An ionic liquid (IL) as a design green solvent is regarded as an attractive alternative or replacement to conventional volatile organic solvent. Ionic liquids (ILs) are low melting point salts composed entirely of ions. They have negligible volatility, low flammability, chemical stability, good environmental benignity, good solubility for organic compounds, and they are miscible with water. Moreover, a large number of possible variations in cation and anion features allowing the fine-tuning of the IL properties [13] [14]. IL based materials interact with analytes through anion exchange, hydrogen bonding and hydrophobic interaction [15]. The extraction of bioactive compounds from plants using ILs is promising as a green method, in reducing the environmental pollution and improving the selectivity and extraction yields of interesting compounds in sample pretreatment processes

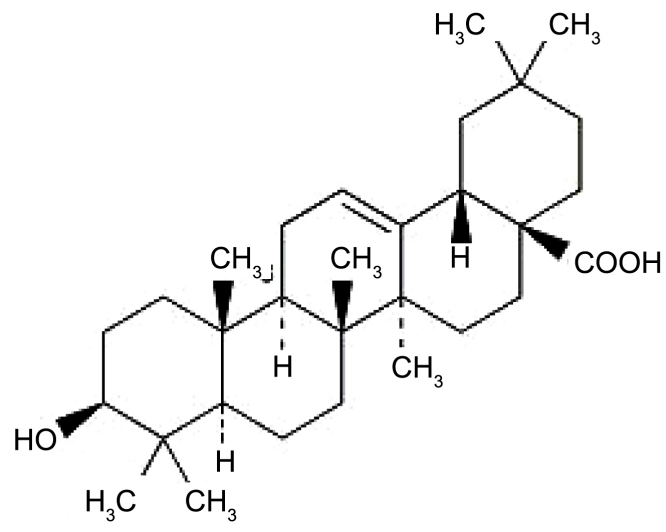

Figure 1. Chemical structure of oleanolic acid. 
compared to conventional organic solvents. IL-assisted sample pretreatment techniques such as aqueous biphasic systems [16], liquid-liquid extraction [17], liquid-phase microextraction [18] and solid-phase microextraction [19] have also been reported. Many researchers have used ILs as solvents for the extraction of the aromatic sulfur compounds [20], henolic compounds [21], flavonoids from Chamaecyparis obtuse leaves [22].

Ultrasound-assisted extraction has been successfully used for the extraction of the bioactive constituents from the plant materials [23] due to advantages of high reproducibility, reduction in extraction time and minimum solvent consumption, temperature and energy output. Recently, ILUAE has been developed, combining the advantages of UAE and beneficial properties of ILS. Therefore, the ILUAE is becoming one of the attractive and promising extraction techniques.

Response surface methodology (RSM) is an effective statistical technique for optimizing complex processes because it allows more efficient and easier arrangement and interpretation of experiments compared to other methods. In addition, it is less laborious and time-consuming than other approaches that applied to optimize a process. It is widely used for optimization of the extraction process of the bioactive ingredients.

To the best of our knowledge, extraction of OA from grape seeds with ILs as the solvent has not yet been reported in the literature. Ultrasound-assisted extraction parameters, such as ionic liquids with different cations and anions concentration, solvent to solid ratio, ultrasonic power, ultrasonication time, and extraction temperature for enhancing the extraction efficiency of OA were systematically optimized. The aim of this work was to develop a rapid, effective, validated and environmental friendly ionic liquid based ultrasound-assisted approach for extraction of OA from grape seeds, and to compare it with conventional solvent extraction.

\section{Materials and Methods}

\subsection{Materials and Reagents}

Grape seeds were obtained from the Bin He food industry Co, Ltd. (Gansu, China). OA (purity $>98 \%$ by HPLC) was purchased from the National Institute for the Control of Pharmaceutical and Biological Products (Beijing, China). All the ionic liquids $\left(\left[\mathrm{C}_{4} \mathrm{mim}\right] \mathrm{Cl},\left[\mathrm{C}_{4} \mathrm{mim}\right] \mathrm{Br},\left[\mathrm{C}_{4} \mathrm{mim}\right] \mathrm{BF}_{4},\left[\mathrm{C}_{4} \mathrm{mim}\right] \mathrm{NO}_{3},\left[\mathrm{C}_{4} \mathrm{mim}\right] \mathrm{HSO}_{4}\right.$, $\left.\left[\mathrm{C}_{4} \mathrm{mim}\right] \mathrm{ClO}_{4}\right)$ purchased from Lanzhou institute of chemical physics, Lanzhou, China. Other materials used in this study were of analytical grade.

\subsection{Optimization of Parameters for IL Based Extraction of $\mathrm{OA}$ from Grape Seeds}

Grape seeds powder $(5 \mathrm{~g})$ was dispersed in $50 \mathrm{ml}$ of IL $(0.5 \mathrm{~mol} / \mathrm{L})$ prepared deionized water by gentle stirring using magnetic stirrer. The extraction was carried out for $1 \mathrm{~h}$ by gentle stirring with magnetic stirrer at a stirring rate of 150 
$\mathrm{r} / \mathrm{min}$ at $35^{\circ} \mathrm{C}$. The extract obtained after IL extraction was filtered using filter paper to remove solid particles and quantified for the content of OA. The extraction yield of OA was defined as follow:

$$
Y(\mathrm{mg} / \mathrm{g})=C V / M
$$

where $C(\mathrm{mg} / \mathrm{mL})$ is the concentration of OA in extract, $V(\mathrm{~mL})$ is the volume of the extract, and $M(\mathrm{~g})$ is the mass of sample weighed.

Six different ILs $\left(\left[\mathrm{C}_{4} \mathrm{mim}\right] \mathrm{Cl}, \quad\left[\mathrm{C}_{4} \mathrm{mim}\right] \mathrm{Br}, \quad\left[\mathrm{C}_{4} \mathrm{mim}\right] \mathrm{BF}_{4}, \quad\left[\mathrm{C}_{4} \mathrm{mim}\right] \mathrm{NO}_{3}\right.$, $\left.\left[\mathrm{C}_{4} \mathrm{mim}\right] \mathrm{HSO}_{4},\left[\mathrm{C}_{4} \mathrm{mim}\right] \mathrm{ClO}_{4}\right)$ were used to screen the most suitable anion to extract OA from grape seeds at $0.5 \mathrm{~mol} / \mathrm{L}$, The selected ILs $\mathrm{Cl}^{-}$and $\mathrm{BF}_{4}^{-}$with different cations $\left(\mathrm{C}_{2} \mathrm{mim}^{+}, \mathrm{C}_{4} \mathrm{mim}^{+}, \mathrm{C}_{6} \mathrm{mim}^{+}, \mathrm{C}_{8} \mathrm{mim}^{+}\right)$were used at $0.5 \mathrm{~mol} / \mathrm{L}$ to investigate the effect of the cation on the extraction efficiency of OA. For maximum extraction of $\mathrm{OA}$, concentration of $\left[\mathrm{C}_{4} \mathrm{mim}\right] \mathrm{Cl}(0.1,0.3,0.5,0.7$ and 0.9 $\mathrm{mol} / \mathrm{L})$, time of extraction $(1-5 \mathrm{~h})$, solvent to solid ratio $(10: 1-30: 1, \mathrm{~mL} / \mathrm{g})$, ultrasonic power $(100-300 \mathrm{~W})$, ultrasonication time (5 - $25 \mathrm{~min})$, and temperature of extraction $\left(30^{\circ} \mathrm{C}-70^{\circ} \mathrm{C}\right)$ were optimized. The process of extraction was done as described above in this section. The IL extracts were then estimated for the content of OA. All the analyses were done in triplicates.

\subsection{Conventional Reference Extraction Method}

The conventional UAE was selected as the reference method for extraction of the target compounds [24]. $1.0 \mathrm{~g}$ sample was extracted under the conditions as follow: ethanol concentration $70 \%(\mathrm{v} / \mathrm{v})$, extraction temperature $25^{\circ} \mathrm{C}$, solvent to solid ratio of 10:1 (mL/g), ultrasonication time $30 \mathrm{~min}$, repeated two times. UAE was performed as a control for comparison with ILUAE. All samples were prepared and analyzed in triplicate.

\subsection{Determination of OA Concentration [25]}

The OA concentration in the top phase and bottom phase was estimated using the colorimetric method of vanillin perchloric acid under the conditions of OA as a standard. To evaporate sample solvent, the sample residue was reacted with $0.3 \mathrm{~mL} 5 \%(\mathrm{w} / \mathrm{v})$ vanillin in glacial acetic acid and $1.0 \mathrm{~mL}$ perchloric acid at $70^{\circ} \mathrm{C}$ in water bath for 25 minutes, the optical density was measured at $548 \mathrm{~nm}$.

\subsection{Experimental Design and Statistical Analysis}

RSM was employed for experimental design, data analysis and model building with software Design Expert (Design-Expert 7.0). A Box behnken Design (BBD) with three variables and three levels was used to determine the response pattern and then to establish a model [26]. According the results of single factors experiment, three independent variables used in this work with three levels for each variable were ultrasonic power $\left(X_{1}\right)$, ultrasonication time $\left(X_{2}\right)$, and extraction temperature $\left(X_{3}\right)$, while the dependent variable was the yield of OA. The experimental range of the selected process variables with their units and notation was 
given in Table 1. Experiments were randomized to maximize the effects of unexplained variability in the observed responses, due to extraneous factors. The response variable, $Y$ can be expressed as a function of the independent process variables according to the following response surface quadratic model

$$
Y_{i}=\beta_{0}+\sum \beta_{i i} X_{i}^{2}+\sum \beta_{i j} X_{i} X_{j}
$$

where $Y_{i}$ is the predicted response, $X_{i} X_{j}$ are input varuables which influence the response variable $Y . \beta_{o}$ is the offset term; $B_{i}$ is the ith linear coefficient; $B_{i i}$ is the ith quadratic coefficient and $B_{\mathrm{ij}}$ is the $i$ th interaction coefficient. Design-expert package (version 7.0, Stat-Ease, Inc., Minneapolis, MN, USA) was used for the experimental design and regression analysis of the data obtained.

The experimental design consisted of twelve factorial points in Table 2, and five replicates at the central point of designed model were used to estimate the pure error sum of squares. The adequacy of the developed model and statistical significance of the regression coefficients were tested using the analysis of variance (ANOVA). p-Values of less than 0.05 were considered to be statistically

Table 1. Experimental factors level table for the RSM study in central composite design.

\begin{tabular}{|c|c|c|c|c|c|}
\hline \multirow{2}{*}{ Factors } & \multirow{2}{*}{ Unit } & \multirow{2}{*}{ Notation } & \multicolumn{3}{|c|}{ Range and levels } \\
\hline & & & -1 & 0 & 1 \\
\hline Ultrasonic power & $\mathrm{W}$ & $X_{1}$ & 150 & 200 & 250 \\
\hline Ultrasonication time & $\min$ & $X_{2}$ & 10 & 15 & 20 \\
\hline Extraction temperature & ${ }^{\circ} \mathrm{C}$ & $X_{3}$ & 40 & 50 & 60 \\
\hline
\end{tabular}

Table 2. Test design and result of response surface method analysis.

\begin{tabular}{ccccc}
\hline Run & $X_{1}$ & $X_{2}$ & $X_{3}$ & $Y(\mathrm{mg} / \mathrm{g})$ \\
\hline 1 & -1 & -1 & 0 & 11.2 \\
2 & 1 & -1 & 0 & 10.1 \\
3 & -1 & 1 & 0 & 9.65 \\
4 & 1 & 1 & 0 & 10.21 \\
5 & -1 & 0 & -1 & 10.21 \\
6 & 1 & 0 & -1 & 9.36 \\
7 & -1 & 0 & 1 & 9.87 \\
8 & 1 & 0 & 1 & 8.56 \\
9 & 0 & -1 & -1 & 12.3 \\
10 & 0 & 1 & -1 & 10.21 \\
11 & 0 & -1 & 1 & 10.23 \\
12 & 0 & 1 & 1 & 10.23 \\
13 & 0 & 0 & 0 & 13.51 \\
14 & 0 & 0 & 0 & 13.24 \\
15 & 0 & 0 & 0 & 13.25 \\
16 & 0 & 0 & 0 & 13.56 \\
17 & 0 & 0 & 0 & 13.26 \\
\hline
\end{tabular}


significant. The interaction among the different independent variables and their corresponding effect on the response were studied by analyzing the response surface 3D plots.

\section{Results and Discussion}

\subsection{Screening of ILs}

The extraction yield of target compounds might be obviously affected by the physical and chemical properties of ionic liquids, while the two properties can be significantly influenced by their structure [27]. To find the optimal ionic liquid for OA extraction and evaluate its influence on the ultrasonic extraction process, 1-alkyl-3-methylimidazolium-type ionic liquids with different anions and cations were researched.

\subsubsection{Influence of the Anion}

The anion identity is considered an obvious factor which can influence the characteristic of ionic liquids, especially for water miscibility [28]. Therefore, $\mathrm{N}$-methylimidazolium based ionic liquids with simple anions $\left(\mathrm{Cl}^{-}, \mathrm{Br}^{-}\right)$and complex anions $\left(\mathrm{BF}_{4}^{-}, \mathrm{NO}_{3}^{-}, \mathrm{HSO}_{4}^{-}\right.$and $\left.\mathrm{CIO}_{4}^{-}\right)$were evaluated. The extraction yields of $\mathrm{OA}$ were obviously different, as shown in Figure 2(a). All of the selected ionic liquids were hydrophilic enough to dissolve in any proportion with water. The results indicated that ionic liquids with $\mathrm{BF}_{4}^{-}$and $\mathrm{Cl}^{-}$anions were more efficient for the extraction of OA. It also confirmed that the OA extraction yield is anion-dependent.

\subsubsection{Influence of Cation}

Six ionic liquids with different cations $\left(\mathrm{C}_{2} \mathrm{mim}^{+}, \mathrm{C}_{4} \mathrm{mim}^{+}, \mathrm{C}_{6} \mathrm{mim}^{+}, \mathrm{C}_{8} \mathrm{mim}^{+}\right)$ combined with $\mathrm{BF}_{4}^{-}$and $\mathrm{Cl}^{-}$were also screened to obtain the optimal extraction yield of OA. The results are shown in Figure 2(b). They indicated that for ionic liquids linked with either $\mathrm{BF}_{4}^{-}$and $\mathrm{Cl}^{-}$, the extraction yield of $\mathrm{OA}$ first increased with the increasing alkyl chain length from ethyl to butyl, and then decreased with the alkyl chain length of the cation increasing from butyl to octyl. Consideration these effects on $\mathrm{OA}$ extraction, $\left[\mathrm{C}_{4} \mathrm{mim}\right] \mathrm{Cl}$ was selected as the optimal extraction solvent for the subsequent extraction parameter optimization studies.

\subsection{Optimization of Single Factor Extraction Conditions}

\subsubsection{Effects of $\left[\mathrm{C}_{4} \mathrm{mim}\right] \mathrm{Cl}$ Concentration on the Yields of $\mathrm{OA}$}

The concentration of $\left[\mathrm{C}_{4} \mathrm{mim}\right] \mathrm{Cl}$ is an important factor that could influence the polarity of solution. The OA concentration affected by $\left[\mathrm{C}_{4} \mathrm{mim}\right] \mathrm{Cl}$ amount was shown in Figure 3(a) different concentrations of $\left[\mathrm{C}_{4} \mathrm{mim}\right] \mathrm{Cl}$ were at $0.1,0.3,0.5$, $0.7,0.9 \mathrm{~mol} / \mathrm{L}$, respectively, while other extraction parameters were: solvent to solid ratio of 15:1, ultrasonic power $200 \mathrm{~W}$, ultrasonication time $15 \mathrm{~min}$, and extraction temperature $50^{\circ} \mathrm{C}$. The maximum $\mathrm{OA}$ yield of $13.55(\mathrm{mg} / \mathrm{g})$ was achieved with $0.7 \mathrm{~mol} / \mathrm{L}$ of $\left[\mathrm{C}_{4} \mathrm{mim}\right] \mathrm{Cl}$ beyond which a decrease in extraction 


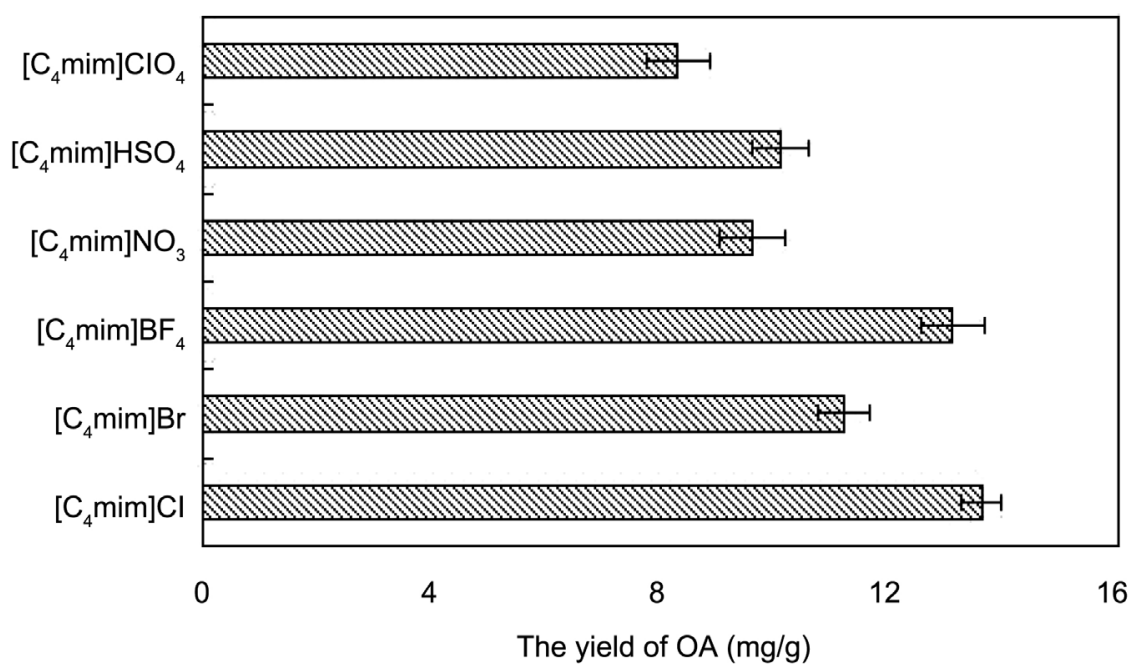

(a)

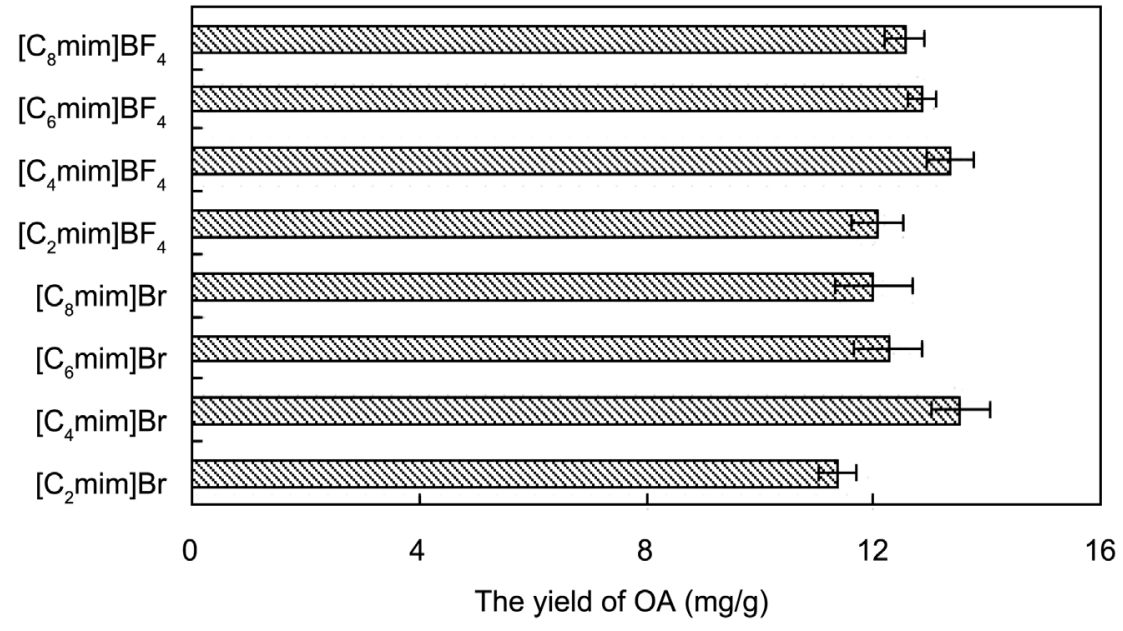

(b)

Figure 2. Influences of ionic liquid anion and cation on the extraction yield of OA.

yield was observed. This may be due to increased viscosity of IL solution at high concentration. High viscosity of IL does not permit its penetration into the plant tissue due to which active compounds cannot be extracted out completely and quickly [26]. Therefore $0.7 \mathrm{~mol} / \mathrm{L}\left[\mathrm{C}_{4} \mathrm{mim}\right] \mathrm{Cl}$ was considered as the optimum concentration and used for further experiments.

\subsubsection{Effects of Extraction Time on the Yields of OA}

To extract target compounds from the cellular structure, a solvent must have access to the cellular compartments of the target compounds. Effect of extraction time was evaluated by varying the extraction time from 2 to $10 \mathrm{~h}$. As shown in Figure 3(b), The extraction field of OA apparently increased as the extraction time increased from 2 to $4 \mathrm{~h}$, and then increased slowly with the longer extraction time (from 4 to $10 \mathrm{~h}$ ). Therefore, $4 \mathrm{~h}$ was selected as the optimal extraction time. 


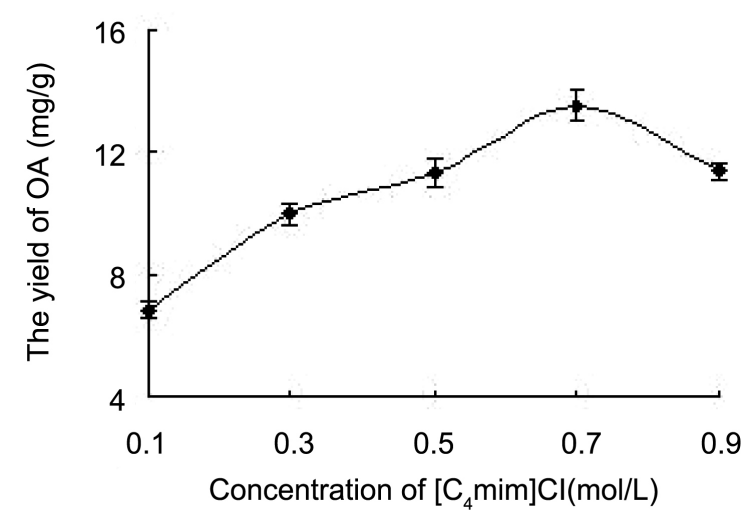

(a)

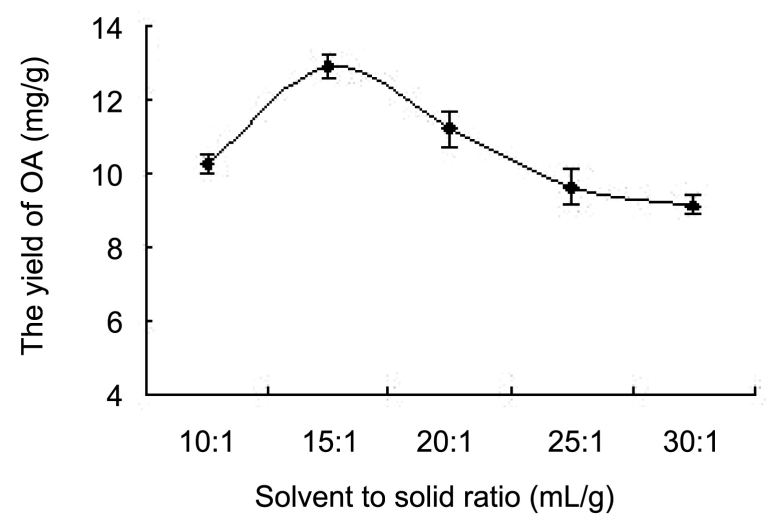

(c)

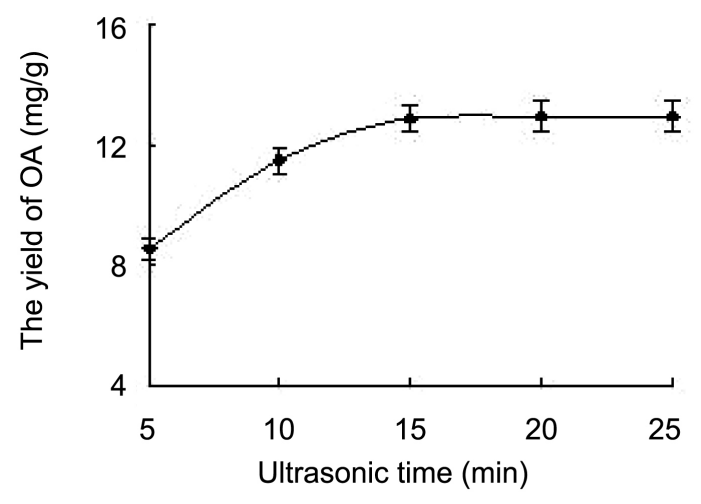

(e)

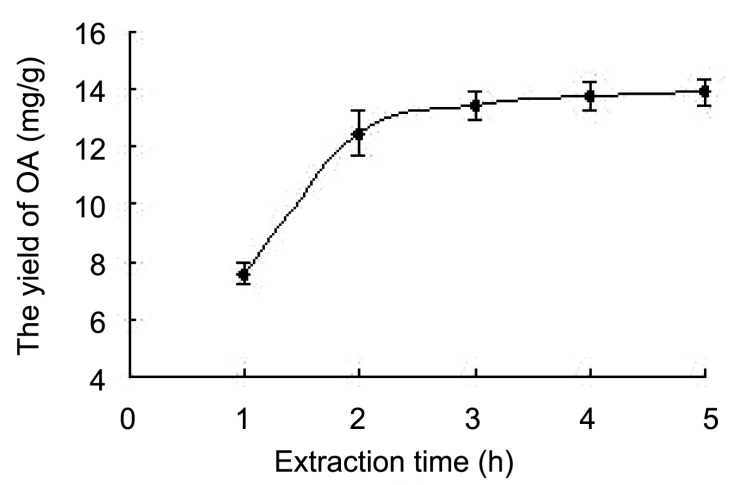

(b)

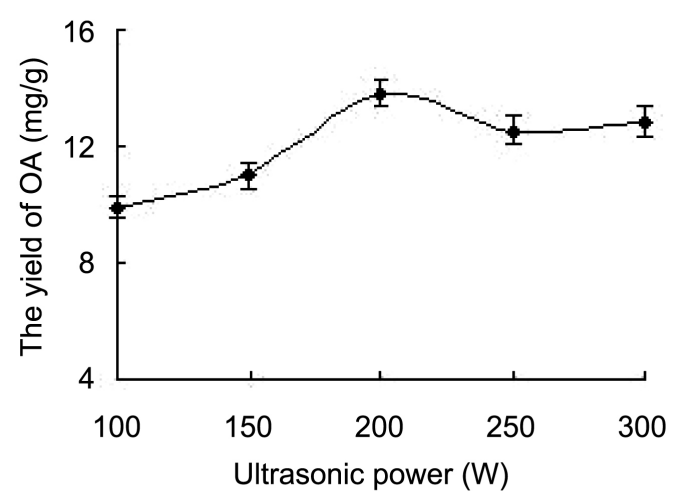

(d)

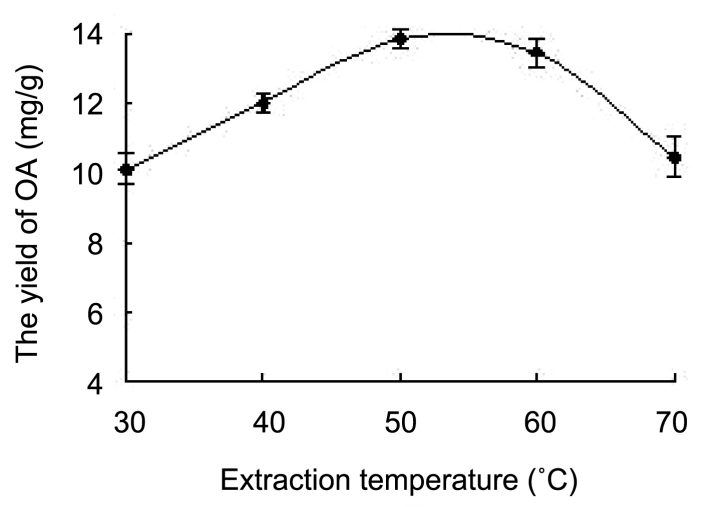

(f)

Figure 3. Single factor experiment. (a) Influences of $\left[\mathrm{C}_{4} \mathrm{mim}\right] \mathrm{Cl}$ concentration $(0.1 \mathrm{~mol} / \mathrm{L}, 0.3 \mathrm{~mol} / \mathrm{L}, 0.5 \mathrm{~mol} / \mathrm{L}, 0.7$ $\mathrm{mol} / \mathrm{L}$, and $0.9 \mathrm{~mol} / \mathrm{L})$; (b) extraction time ( $1 \mathrm{~h}, 2 \mathrm{~h}, 3 \mathrm{~h}, 4 \mathrm{~h}$, and $5 \mathrm{~h})$; (c) solvent to solid ratio $(10 \mathrm{~mL} / \mathrm{g}, 15 \mathrm{~mL} / \mathrm{g}, 20$ $\mathrm{mL} / \mathrm{g}, 25 \mathrm{~mL} / \mathrm{g}$, and $30 \mathrm{~mL} / \mathrm{g}$ ); (d) Ultrasonic power ( $100 \mathrm{~W}, 150 \mathrm{~W}, 200 \mathrm{~W}, 250 \mathrm{~W}$, and $300 \mathrm{~W})$; (e) Ultrasonication time (5 min, $10 \mathrm{~min}, 15 \mathrm{~min}, 20 \mathrm{~min}$, and $25 \mathrm{~min}$ ). (f) Extraction temperature $\left(30^{\circ} \mathrm{C}, 40^{\circ} \mathrm{C}, 50^{\circ} \mathrm{C}, 60^{\circ} \mathrm{C}\right.$, and $70^{\circ} \mathrm{C}$ ).

\subsubsection{Effects of Solvent to Solid Ratio on the Yields of OA}

The solvent volume must be sufficient to ensure that the entire sample is immersed, especially when having a matrix that will well during the extraction process. In this study, five different solvent to solid ratios (10:1, 15:1, 20:1, 25:1 and $30: 1(\mathrm{~mL} / \mathrm{g}))$ with $0.7 \mathrm{~mol} / \mathrm{L}\left[\mathrm{C}_{4} \mathrm{mim}\right] \mathrm{Cl}$, were selected to evaluate the influence of solvent to solid ratio on the extraction field of OA from grape seeds. 
Figure 3(c) show that the extraction efficiency of OA increased when the solvent to solid ratio was increased from 10:1 to 15:1. It decreased as the ratio was above $15: 1$. This was probably because a lower solvent to solid ratio was enough for extraction, and ultrasonic energy might be absorbed and dispersed by a larger volume of solvent, which was disadvantageous to the ultrasonic assistant extraction [29]. Therefore, solvent to solid ratio of $15: 1(\mathrm{~mL} / \mathrm{g})$ was suitable for the extraction.

\subsubsection{Effects of Ultrasonic Power on the Yields of OA}

During ionic liquid-based ultrasound assisted extraction (ILUAE), optimization of the ultrasonic power is very important to ensure efficient extraction of the target compounds. The mechanical effects of ultrasound induce a greater penetration of solvent into cellular materials and improve mass transfer. Efficient cell disruption and effective mass transfer are reported as major factors leading to the enhancement of extraction with ultrasonic power [29]. Hence, experiments were carried out at 100,150,200, 250 and $300 \mathrm{~W}$, respectively, while other extraction parameters were: $\left[\mathrm{C}_{4} \mathrm{mim}\right] \mathrm{Cl}$ concentration $0.7 \mathrm{~mol} / \mathrm{L}$ solvent to solid ratio of $15: 1$, extraction temperature $50^{\circ} \mathrm{C}$ and ultrasonication time $15 \mathrm{~min}, \mathrm{~A}$ maximum yield of OA of $13.84(\mathrm{mg} / \mathrm{g}$ ) was achieved at power of $200 \mathrm{~W}$ (Figure $3(d))$. The extraction efficiency increased until power of $200 \mathrm{~W}$ beyond which there was smoothly decreased. Hence $150-250 \mathrm{~W}$ was chosen as the ultrasonic power in the BBD process.

\subsubsection{Effects of Ultrasonication Time on the Yields of $\mathrm{OA}$}

To optimize the ultrasonication time, experiments were carried out for 5 - 25 min with an interval of $5 \mathrm{~min}$, while the other four factors (extraction temperature, ultrasonic power, solvent to solid ratio and the concentration of $\left[\mathrm{C}_{4} \mathrm{mim}\right] \mathrm{Cl}$ ) were fixed at $50^{\circ} \mathrm{C}, 200 \mathrm{~W}, 15: 1$ and $0.7 \mathrm{~mol} / \mathrm{L}$, respectively. It showed that the field of $\mathrm{OA}$ increased with the ultrasonication time ascended from 5 to $15 \mathrm{~min}$ the maximum concentration of OA was observed when the ultrasonication time was $15 \mathrm{~min}$, after this point, the concentration of OA started to maintain a dynamic equilibrium with the increasing of ultrasonication time, and OA concentration was growing slowly when the ultrasonication time exceeded 15 min (Figure 3(e)). Therefore, the range of time from 10 to 20 min was chosen as the ultrasonication time in the BBD process.

\subsubsection{Effects of Extraction Temperature on the Yields of $\mathrm{OA}$}

The yield of OA was increased with the increase of the extraction temperature due to the increase of the mass transfer rate and the solubility of OA. In order to study the effect of different temperatures on the yield of $\mathrm{OA}$, extraction process was carried out by using different temperatures of $20^{\circ} \mathrm{C}, 30^{\circ} \mathrm{C}, 40^{\circ} \mathrm{C}, 50^{\circ} \mathrm{C}, 60^{\circ} \mathrm{C}$, and $70^{\circ} \mathrm{C}$, while the other extraction conditions were: ultrasonication time 15 min, ultrasonic power $200 \mathrm{~W}$ and solvent to solid ratio of 15:1. The yield of OA was increased with enhancing of extraction temperature increased from $20^{\circ} \mathrm{C}$ to $50^{\circ} \mathrm{C}$. As shown in Figure $3(\mathrm{f})$, the maximum field $(13.87(\mathrm{mg} / \mathrm{g}))$ of OA was 
observed when temperature was $50^{\circ} \mathrm{C}$. When extraction temperature varied from $60^{\circ} \mathrm{C}$ to $70^{\circ} \mathrm{C}$, the $\mathrm{OA}$ concentration was smoothly decreased. A coin has two sides: higher temperature can exactly enhance the solubility of OA and the extraction rate; however, the exorbitant extraction temperature also can cause the degradation of $\mathrm{OA}$. Therefore, $40^{\circ} \mathrm{C}-60^{\circ} \mathrm{C}$ was chosen as the extraction temperature in the $\mathrm{BBD}$ process.

\subsection{RSM Modeling and Optimization of Reactive Extraction Process}

In this work, the input variables (factors) and their levels were selected, based on single factor experiments mentioned above. The factors and their actual and coded levels were presented in Table 1 . The BBD was employed to carry out reactive extraction experiments. According to $\mathrm{BBD}$ a number of 17 experimental runs were performed to investigate the reactive extraction process. Each run represents a unique combination of factors levels and for each experiment the yield of OA $Y(\mathrm{mg} / \mathrm{g})$ was determined as it was shown in Table 2. Based on experimental design (Table 2). Results also showed that the yield of OA ranged from $8.56 \%$ to $13.56 \%$. The second order polynomial model in terms of coded variables that approximates the yield of reactive extraction process may be written as follow:

$$
\begin{aligned}
\mathrm{Y}= & +13.36-0.34 \mathrm{~A}-0.44 \mathrm{~B}-0.40 \mathrm{C}+0.41 \mathrm{AB}-0.11 \mathrm{AC} \\
& +0.52 \mathrm{BC}-2.16 \mathrm{~A} 2-0.92 \mathrm{~B} 2-1.71 \mathrm{C} 2
\end{aligned}
$$

The statistical significance of the regression model was checked by F-test and p-value, and the analysis of variance (ANOVA) for the response surface quadratic model was shown in Table 3. The Model F-value of 59.43 implies the model was significant. The p-value were used as a tool to check the significance of each coefficient, and the smaller the p-value was, the more significant the corresponding coefficient was. There is only a $0.01 \%$ chance that a "Model F-value" this large could occur due to noise. p-value less than 0.0500 indicate model terms are significant. It also can be seen that the linear coefficient $\left(X_{1}, X_{2}\right.$, $\left.X_{3}\right)$, the interaction term coefficients $\left(X_{1} X_{2}, X_{2} X_{3}\right)$, and quadratic term coefficients $\left(X_{1}^{2}, X_{2}^{2}, X_{3}^{2}\right)$ were significant, with very small $\mathrm{p}$-values $(\mathrm{p}<0.05)$, the results indicated that ultrasonic power, ultrasonication time and extraction temperature were significantly correlated with the yield of OA. The "Lack of Fit p-value" of 0.0508 implies the Lack of Fit is not significant relative to the pure error. There is a $5.08 \%$ chance that a "Lack of Fit F-value" this large could occur due to noise.

After the response surface regression procedure, the coefficient of determination $\left(\mathrm{R}^{2}\right)$ of the predicted model was 0.9704 , suggesting a good fit, the predicted model (0.8249) seemed to reasonably represent the observed values. Thus, the response was sufficiently explained by the model. "Adeq Precision" measures the signal to noise ratio. A ratio greater than 4 is desirable. The ratio of 21.29 indicates an adequate signal. This model can be used to navigate the design 
Table 3. Variance analysis of regression equations.

\begin{tabular}{ccccccc}
\hline Source & Sum of Squares & df & Mean Square & F Value & $\begin{array}{c}\text { p-value } \\
\text { Prob }>\text { F }\end{array}$ & \\
\hline Model & 44.57512853 & 9 & 4.952792059 & 59.43741059 & $<0.0001$ & significant \\
$X_{1}$ & 0.91125 & 1 & 0.91125 & 10.93571863 & 0.0130 & \\
$X_{2}$ & 1.5576125 & 1 & 1.5576125 & 18.69257837 & 0.0035 & \\
$X_{3}$ & 1.2720125 & 1 & 1.2720125 & 15.26515314 & 0.0058 & \\
$X_{1} X_{2}$ & 0.6889 & 1 & 0.6889 & 8.267343283 & 0.0238 & \\
$X_{1} X_{3}$ & 0.0529 & 1 & 0.0529 & 0.634841718 & 0.4518 & \\
$X_{2} X_{3}$ & 1.092025 & 1 & 1.092025 & 13.1051612 & 0.0085 & \\
$X_{1}^{2}$ & 19.61281289 & 1 & 19.61281289 & 235.3692219 & $<0.0001$ & \\
$X_{2}^{2}$ & 3.530939211 & 1 & 3.530939211 & 42.37405511 & 0.0003 & \\
$X_{3}^{2}$ & 12.25087605 & 1 & 12.25087605 & 147.020174 & $<0.0001$ & \\
Residual & 0.583295 & 7 & 0.083327857 & & & \\
Lack of Fit & 0.484375 & 3 & 0.161458333 & 6.528844858 & 0.0508 & not significant \\
Pure Error & 0.09892 & 4 & 0.02473 & & & \\
Cor Total & 45.15842353 & 16 & & & &
\end{tabular}

space. The coefficient of variation (CV) is the ratio of the standard error of estimate to the mean value of observed response expressed as a percentage. It is a measure of reproducibility of the models. The $\mathrm{CV}$ of the model was calculated as $2.60 \%$. As a general rule, a model can be considered reasonably reproducible if its $\mathrm{CV}$ is not greater than $10 \%$.

The 3D response surface plots were drawn to illustrate the main and interactive effects of the independent variables on the dependent one in Figure 4. They showed the type of interactions between two tested variables and the relationship between responses and experimental levels of each variable. Two variables within the third variable were kept constant at zero level. As shown in Figure 4, the influencing rule of ultrasonic power, ultrasonication time and extraction temperature on the extraction process was similar to the single factor experiments. However, in Figure 4(a) and Figure 3(c), the interaction effect between ultrasonic power $\left(X_{1}\right)$ and ultrasonication time $\left(X_{2}\right)$, between ultrasonication time $\left(X_{2}\right)$ and extraction temperature $\left(X_{3}\right)$, were obvious than others.

By prediction with computing program, the optimal conditions to obtain the highest yield of OA were determined as follows: the ultrasonic power of $195 \mathrm{~W}$, the ultrasonication time of $13.5 \mathrm{~min}$, and extraction temperature of $48.4^{\circ} \mathrm{C}$. At last because of the limit of instruments, the optimal conditions were chosen at the ultrasonic power of $195 \mathrm{~W}$, the ultrasonication time of $13 \mathrm{~min}$, and extraction temperature of $48^{\circ} \mathrm{C}$. The extraction yield of $\mathrm{OA}$ was $13.4 \mathrm{mg} / \mathrm{g}$ with a relative error about $0.6 \%$. 


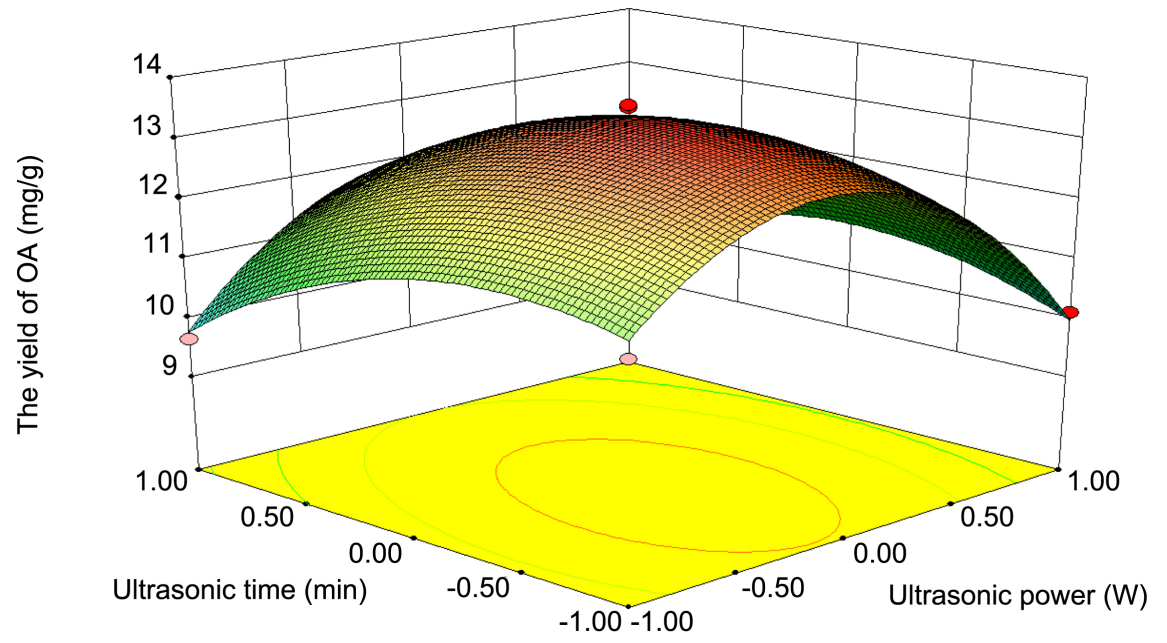

(a)

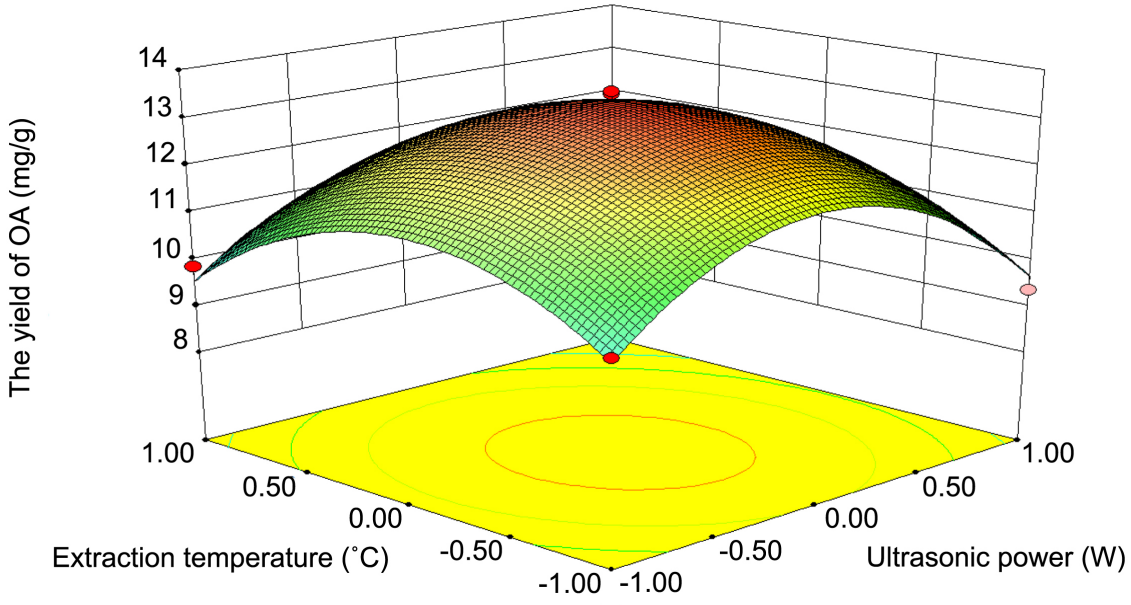

(b)

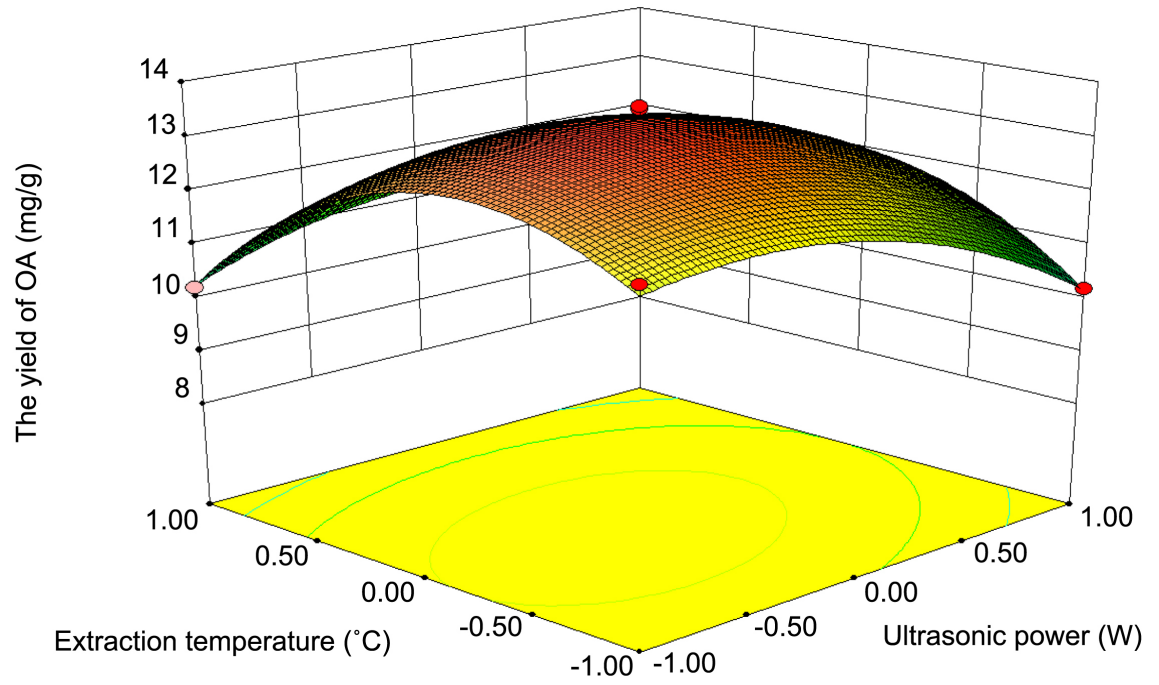

(c)

Figure 4. Response surface plots showing the effects of variables on extraction yield of OA. (a) Interaction of ultrasonic power and ultrasonication time; (b) Interaction of ultrasonic power and extraction temperature; (c) Interaction of ultrasonication time and extraction temperature. 


\subsection{Comparison of the Proposed ILUAE Approach with the UAE Method}

In order to compare the extraction field of the $\left[\mathrm{C}_{4} \mathrm{mim}\right] \mathrm{Cl}$ solution with organic solvent, ethanol was used to extract $\mathrm{OA}$ from grape seeds under the respective optimal condition. Under the optimal conditions of acetone extraction [24], including ethanol concentration $70 \%(\mathrm{v} / \mathrm{v})$, extraction temperature $25^{\circ} \mathrm{C}$, solvent to solid ratio of 10:1 (mL/g), ultrasonication time $30 \mathrm{~min}$, repeated two times. The results of extraction effect of ILUAE and UAE were showed in Figure 5. The extraction yields of OA obtained by ILUAE and UAE were 13.4 and 8.43 $\mathrm{mg} / \mathrm{g}$, respectively. Compared with the regular UAE, the proposed approach exhibited higher efficiency (increase 1.59 time), which indicated that ILUAE was an efficient, rapid and simple sample preparation technique for extraction of the OA from grape seeds. This can be attributed to the better solubility of OA in IL solution due to $\pi-\pi$, ionic/charge-charge interactions or hydrogen bonding between both ion and OA [30].

\section{Conclusion}

In this study, we have come up with a novel ILUAE for extraction of OA from grape seeds. In consideration of the influence of both the anion and cation of ionic liquids, $\left[\mathrm{C}_{4} \mathrm{mim}\right] \mathrm{Cl}$ was selected for the subsequent analysis. The ultrasonic-assisted extraction conditions were optimized using single factor experiments and $\mathrm{BBD}$ in detail. Under these optimal conditions (e.g. with $0.7 \mathrm{~mol} / \mathrm{L}$ $\left[\mathrm{C}_{4} \mathrm{mim}\right] \mathrm{Cl}$, solvent to solid ratio of $15: 1$, extraction time $4 \mathrm{~h}$, ultrasonic power $195 \mathrm{~W}$, ultrasonication time $13 \mathrm{~min}$, and extraction temperature of $48^{\circ} \mathrm{C}$ ), this approach gained the highest extraction yield of OA $13.4 \mathrm{mg} / \mathrm{g}$. Compared with conventional regular ultrasonic extraction, the proposed approach provides higher extraction efficiency, and obviously reduced extraction time. The proposed ILUAE has abroad prospect in sample preparation of bioactive compounds.

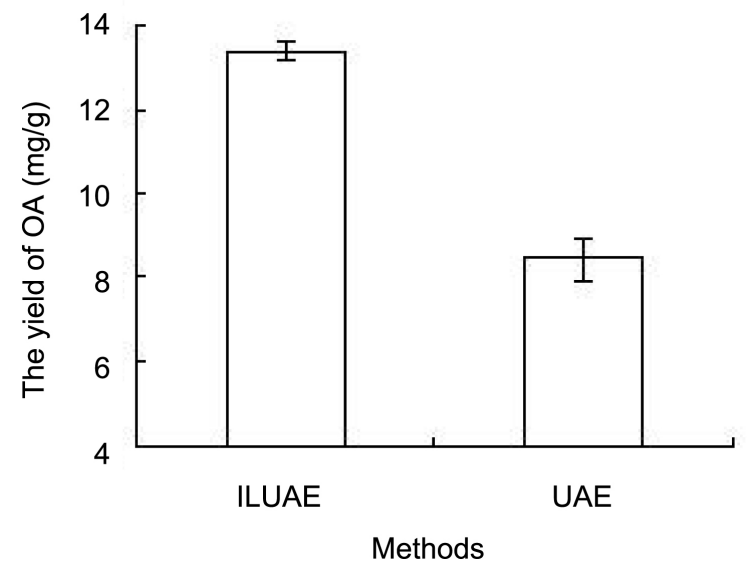

Figure 5. Comparison of the proposed ILUAE with the UAE method. 


\section{Acknowledgements}

The authors would like to acknowledge the financial support by National undergraduate training programs for innovation and entrepreneurship (No. 201510740005).

\section{Conflict of Interest}

The authors declared that they have no conflicts of interest to this work. We declare that we do not have any commercial or associative interest that represents a conflict of interest in connection with the work submitted.

\section{References}

[1] Maier, T., Göppert, A., Kammerer, D.R., Schieber, A. and Carle, R. (2008) Optimization of a Process for Enzyme-Assisted Pigment Extraction from Grape (Vitis vinifera L.) Pomace. European Food Research and Technology, 227, 267-275. https://doi.org/10.1007/s00217-007-0720-y

[2] Özvural, E.B. and Vural, H. (2014) Which Is the Best Grape Seed Additive for Frankfurters: Extract, Oil or Flour? Journal of the Science of Food and Agriculture, 94, 792-797. https://doi.org/10.1002/jsfa.6442

[3] Chemat, F., Li. Y., Tomao, V., Ginies, C. and Cravotto, G. (2013) Optimization of Procedures for In-Line Extraction of Lipids and Polyphenols from Grape Seeds. Food Analytical Methods, 7, 459-464. https://doi.org/10.1007/s12161-013-9646-0

[4] Gazzola, D., Vincenzi, S., Gastaldon, L., Tolin, S., Pasini, G. and Curioni, A. (2014) The Proteins of the Grape (Vitis vinifera L.) Seed Endosperm: Fractionation and Identification of the Major Components. Food Chemistry, 155, 132-139. https://doi.org/10.1016/j.foodchem.2014.01.032

[5] Yunoki, K., Sasaki, G., Tokuji, Y., Kinoshita, M., Naito, A., Aida, K. and Ohnishi, M. (2008) Effect of Dietary Wine Pomace Extract and Oleanolic Acid on Plasma Lipids in rats Fed High-Fat Diet and Its DNA Microarray Analysis. Journal of Agricultural and Food Chemistry, 56, 12052-12058. https://doi.org/10.1021/jf8026217

[6] Pensec, F., Paczkowski, C., Grabarczyk, M., Wozniak, A., Bénard-Gellon, M., Bertsch, C. and Szakiel, A. (2014) Changes in the Triterpenoid Content of Cuticular Waxes during Fruit Ripening of Eight Grape (Vitis vinifera) Cultivars Grown in the Upper Rhine Valley. Journal of Agricultural and Food Chemistry, 62, 7998-8007. https://doi.org/10.1021/jf502033s

[7] Wang, X.X., Ye, L., Liu, R., Chen, H.L., Bai, H., Liang, X. and Hai, C.X. (2010) Antioxidant Activities of Oleanolic Acid in Vitro: Possible Role of Nrf2 and MAP Kinases. Chemico-Biological Interactions, 184, 328-337. https://doi.org/10.1016/j.cbi.2010.01.034

[8] Lee, W., Yang, E.J., Ku, K., Song, K.S. and Bae, J.S. (2013)Anti-Inflammatory Effects of Oleanolic Acid on LPS-Induced Inflammation in Vitro and in Vivo. Inflammation, 36, 94-102. https://doi.org/10.1007/s10753-012-9523-9

[9] Ghosh, S., Bishayee, K. and Khuda-Bukhsh, A.R. (2014) Oleanolic Acid Isolated from Ethanolic Extract of Phytolacca decandra Induces Apoptosis in A375 Skin Melanoma Cells: Drug-DNA Interaction and Signaling Cascade. Journal of Integrative Medicine, 12, 102-114. https://doi.org/10.1016/S2095-4964(14)60015-7

[10] Mahapatra, A., Chauhan, N., Patel, D.R., Kalia, N.P., Rajput, V.S. and Khan, I.A. (2014) Synthesis and Antitubercular Activity of Oleanolic Acid Analogs. Pharma- 
ceutical Chemistry Journal, 48, 39-43. https://doi.org/10.1007/s11094-014-1042-6

[11] Wójciak-Kosior, M., Sowa, I., Kocjan, R. and Nowak, R. (2013) Effect of Different Extraction Techniques on Quantification of Oleanolic and Ursolic Acid in Lamii Albi Flos. Industrial Crops and Products, 44, 373-377. https://doi.org/10.1016/j.indcrop.2012.11.018

[12] Chronopoulou, L., Agatone, A.C. and Palocci, C. (2013) Supercritical $\mathrm{CO}_{2}$ Extraction of Oleanolic Acid from Grape Pomace. International Journal of Food Science \& Technology, 48, 1854-1860.

[13] Cláudio, A.F.M., Freire, M.G., Freire, C.S., Silvestre, A.J. and Coutinho, J.A. (2010) Extraction of Vanillin Using Ionic-Liquid-Based Aqueous Two-Phase Systems. Separation and Purification Technology, 75, 39-47.

[14] Liu, L., He, L., Jiang, X., Zhao, W., Xiang, G. and Anderson, J.L. (2014) Macrocyclic Polyamine-Functionalized Silica as a Solid-Phase Extraction Material Coupled with Ionic Liquid Dispersive Liquid-Liquid Extraction for the Enrichment of Polycyclic Aromatic Hydrocarbons. Journal of Separation Science, 37, 1004-1011. https://doi.org/10.1002/jssc.201301062

[15] Wanigasekara, E., Perera, S., Crank, J.A., Sidisky, L., Shirey, R., Berthod, A. and Armstrong, D.W. (2010) Bonded Ionic Liquid Polymeric Material for Solid-Phase Microextraction GC Analysis. Analytical and Bioanalytical Chemistry, 396, 511-524. https://doi.org/10.1007/s00216-009-3254-2

[16] Gao, J., Chen, L. and Yan, Z.C. (2014) Extraction of Dimethyl Sulfoxide Using Ionic-Liquid-Based Aqueous Biphasic Systems. Separation and Purification Technology, 124, 107-116. https://doi.org/10.1016/j.seppur.2014.01.015

[17] Gharehbaghi, M. and Shemirani, F. (2012) A Novel Method for Dye Removal: Ionic Liquid-Based Dispersive Liquid-Liquid Extraction (IL-DLLE). CLEAN-Soil, Air, Water, 40, 290-297. https://doi.org/10.1002/clen.201100258

[18] Han, D., Tang, B., Ri, Y., Lee, K. and Row, Ho. (2012) Application of Ionic Liquid in Liquid Phase Microextraction Technology. Journal of Separation Science, 35, 2949 2961. https://doi.org/10.1002/jssc.201200486

[19] Hsieh, Y.N., Huang, P.C., Sun, I.W., Whang T.J., Hsu, C.Y., Huang, H.H. and Kuei, C.H. (2012) Nafion Membrane-Supported Ionic Liquid-Solid Phase Microextraction for Analyzing Ultra Trace PAHs in Water Samples. Analytica Chimica Acta, 557, 321-328. https://doi.org/10.1016/j.aca.2005.10.019

[20] Jiang, W., Zhu, W., Li, H., Wang, X., Yin, S., Chang, Y. and Li, H. (2015) Temperature-Responsive Ionic Liquid Extraction and Separation of the Aromatic Sulfur Compounds. Fuel, 140, 590-596. https://doi.org/10.1016/j.fuel.2014.09.083

[21] Huang, F., Berton, P., Lu, C., Siraj, N., Wang, C., Magut, P.K. and Warner, I.M. (2014) Surfactant-Based Ionic Liquids for Extraction of Phenolic Compounds Combined with Rapid Quantification Using Capillary Electrophoresis. Electrophoresis, 35, 2463-2469. https://doi.org/10.1002/elps.201300589

[22] Tang, B., Lee, Y.J., Lee, Y.R. and Row, K.H. (2013) Examination of 1-Methylimidazole Series Ionic Liquids in the Extraction of Flavonoids from Chamaecyparis obtuse Leaves Using a Response Surface Methodology. Journal of Chromatography B, 933, 8-14. https://doi.org/10.1016/j.jchromb.2013.06.023

[23] Yang, L., Wang, H., Zu, Y.G., Zhao, C., Zhang, L., Chen, X. and Zhang, Z. (2011) Ultrasound-Assisted Extraction of the Three Terpenoid Indole Alkaloids Vindoline, Catharanthine and Vinblastine from Catharanthus roseus Using Ionic Liquid Aqueous Solutions. Chemical Engineering Journal, 172, 705-712. https://doi.org/10.1016/j.cej.2011.06.039 
[24] Duba, K.S., Casazza, A.A., Mohamed, H.B., Perego, P. and Fiori, L. (2015) Extraction of Polyphenols from Grape Skins and Defatted Grape Seeds Using Subcritical Water: Experiments and Modeling. Food and Bioproducts Processing, 94, 29-38. https://doi.org/10.1016/j.fbp.2015.01.001

[25] Wang, B.Z. and Xie, H.X. (2014) Determination of Concentration of Total Saponins and Oleanolic Acid of Rubus sachalinensis at Different Collecting Time. Chinese Journal of Experiment Medical Formulae, 20, 77-79.

[26] Harde, S.M., Lonkar, S.L., Degani, M.S. and Singhal, R.S. (2014) Ionic Liquid Based Ultrasonic-Assisted Extraction of Forskolin from Coleus forskohlii Roots. Industrial Crops and Products, 61, 258-264. https://doi.org/10.1016/j.indcrop.2014.07.016

[27] Da Porto, C., Porretto, E. and Decorti, D. (2013) Comparison of Ultrasound-Assisted Extraction with Conventional Extraction Methods of Oil and Polyphenols from Grape (Vitis vinifera L.) Seeds. Ultrasonics Sonochemistry, 20, 1076-1080. https://doi.org/10.1016/j.ultsonch.2012.12.002

[28] Huddleston, J.G., Visser, A.E., Reichert, W.M., Willauer, H.D., Broker, G.A. and Rogers, R.D. (2013) Characterization and Comparison of Hydrophilic and Hydrophobic Room Temperature Ionic Liquids Incorporating the Imidazolium Cation. Green Chemistry, 3, 156-164. https://doi.org/10.1039/b103275p

[29] Lin, H., Zhang, Y., Han, M. and Yang, L. (2013) Aqueous Ionic Liquid Based Ultrasonic Assisted Extraction of Eight Ginsenosides from Ginseng Root. Ultrasonics Sonochemistry, 20, 680-684. https://doi.org/10.1016/j.ultsonch.2012.10.003

[30] Bogdanov, M.G. and Svinyarov, I. (2013) Ionic Liquid-Supported Solid-Liquid Extraction of Bioactive Alkaloids. II. Kinetics, Modeling and Mechanism of Glaucine Extraction from Glaucium flavum Cr. (Papaveraceae). Separation and Purification Technology, 103, 279-288. 